Onomastica Slavogermanica

XXXI

Wrocław 2019

DOI: $10.19195 / 0474-1471.31 .6$

SVATOPLUK PASTYŘíK

Hradec Králové

\title{
Rozlehlá krajina jmen v literárním díle Oty Hofmana
}

Klíčová slova: Ota Hofman, literární text, vlastní jména

V letošním roce si česká čtenářská veřejnost připomíná nedožité devadesátiny spisovatele, scenáristy, dramatika, autora sci-fi Oty Hofmana (1928-1989). Fakulta sociálních věd UK Praha a Krajská vědecká knihovna Liberec uspořádaly v dubnu k autorovu výročí narození dvoudenní česko-německou konferenci „Odkaz Oty Hofmana literatuře a filmu“.

\section{Jak vidí Hofmanovo literární dílo literární onomastika?}

Podle teoretika české dětské literatury Otokara Chaloupky uplatňuje Ota Hofman ve svých prózách „fabulační šíri i situační konkrétnost filmařského vidění [...] dovede najít adekvátní tvưrčí výraz, přičemž vždy si podržuje své výrazové charakteristiky návaznosti dějových sekvencí, akčního členění příběhu a konkrétního plastického vidění situace, v níž se prríběh odehrávác“ (s. 117). ${ }^{1}$ A právě prizmatem literárně onomastickým bychom se chtěli mimo jiné podívat na Chaloupkova slova o Hofmanově „plastickém vidění situace, v níž se př́běh odehrává“, jsou-li pravdivá čili nic. Zejména vlastní jména totiž vždy situaci konkretizují a determinují oproti situacím jiným, postavy i místa identifikují, event. klasifikují a charakterizují. Zamýšlení nad literárními vlastními jmény je tedy podmíněno rozpoznáním a identifikací funkcí vlastních jmen v literárním textu. ${ }^{2}$ Bude tudíž i naším vůdčím principem při pohledu na prozaické dílo Oty Hofmana.

${ }^{1}$ O. Chaloupka a kol., Čeští spisovatelé literatury pro děti a mládež, Praha 1985.

2 Bliže a více o tom Ž. Dvořáková, Literární onomastika, Praha 2017. 
Literární věda vyděluje v Hofmanově díle skupinu moderních pohádek, které autor publikoval v šedesátých a sedmdesátých letech minulého století (Pohádka o staré tramvaji, 1961; Klaun Ferdinand a raketa, 1965; Hodina modrých slonü, 1969; Pan Tau a tisíc zázraki̊, 1974; Lucie, postrach ulice, 1980), dále pak př́ibèhové prózy s dětskými hrdiny, které psal rovněž v tomto období (Králíci ve vysoké trávě, 1962; Útěk, 1966; Cesta na planetu Mikymaus, 1969; Červená kůlna, 1974), v sedmdesátých letech publikoval ještě knihy s prvky sci-fi (Čtvrtý rozměr, 1970; Odysseus a hvězdy, 1976).

Je zřejmé, že v tolika různých knihách bude také velké množství vlastních jmen, a to různého druhu. Je jich skutečně tolik, že vytvářejí poměrně rozlehlou a rozsáhlou „krajinu jmen“. Nechceme je však tradičně zkoumat kvantitativně, chtěli bychom se na vlastní jména v Hofmanově tvorbě podívat spíše z kvalitativního hlediska, a to zejména $\mathrm{z}$ hlediska funkčního.

Základní funkcí vlastních jmen v literárním textu je v případě literárních hrdinů identifikace a individualizace postav, jejich odlišení od postav jiných. Platí to samozřejmě především o literárních antroponymech, kterými se literární onomastikové prozatím zabývají nejvíce. Méně jsou už bohužel zkoumána literární toponyma a chrématonyma. Ale i takové zkoumání by však mohlo dobře přispět k hlubšímu poznání např́íklad zákonitostí vývoje dětské čtenářské gramotnosti.

V potaz je však nutno vzít i literární druh, žánr, dobovou poetiku, v neposlední řadě rovněž také autorské stylistické záměry. Určitě by stálo za to, využít při literárně onomastickém šetření i těchto výše uvedených literárně teoretických aspektů. Samozřejmě pak je také potřeba přihlédnout ke čtenářským aspektům, zejména pak v dětské literatuře $\mathrm{k}$ ontogenezi dětského čtenáře.

\section{Jak je tomu z hlediska literární onomastiky v Hofmanových prózách pro děti?}

V knihách Oty Hofmana, at' už se jedná o moderní pohádky, příběhy s dětskými hrdiny nebo knihy sci-fi, se bez žánrového rozlišení ${ }^{3}$ (jedná se o první sondu, čistě materiálovou, do díla tohoto autora) vyskytuje značné množství vlastních jmen, které především ukotvují svou reálnou podobou př́iběhy v místě a čase.

Kulisou většiny Hofmanových knih je Praha, připomínaná především reálnými urbanonymy (například Velká Praha, Staré Město, Nové Město, Letná, Žižkov, Vršovice, Vinohrady, Malešice, Libeň, Pankrác, Hanspaulka, Palmovka,

${ }^{3}$ Zcela jinak je tomu např́iklad v prózách Boženy Němcové, která výrazně odlišuje literární jména postav v pohádkách a v povídkách. Viz o tom S. Pastyř́ík, Hypokoristika v povídkách Boženy Němcové. In: Prameny díla, dílo pramenem, ed. J. Bartůňková, Hradec Králové 1995, s. 191196; M. Majtánová, Vlastní jména osob v Národních báchorkách a pověstech Boženy Němcové, ZMK, 12, 1971, s. 377-387; eadem, Jména postav ve ,, Slovenských pohádkách” Boženy Němcové, ZMK, 13, 1972, s. 391-397. 
Vysočany, Pelc-Tyrolka, linka Olšanské hřbitovy - Bílá hora, Václavské náměstí, Karlovo náměstí, Muzeum, Hrad, Vyšehrad, Národní divadlo, Olšany, Zelená liška, kavárna Alfa, kavárna Demínka, Ohrada, Vápenka, Kolínská ulice, Nuselské schody, Panská ulice, Kampa etc.). Ta mají, podle našeho soudu, funkci identifikační, většina však jen funkci ilustrační.

Další reálná toponyma domácí (např́íklad Český les, Pootaví, Velké Meziřičí, Mirošsovice, Brno, Ostrava, Dobř̌̌šs, Jilovištěe, Valkeřice, Heřmanice, Jiřice, Jabkenice, Chrudim, Senohraby, Znojmo, Hostérádky, Sobotka, Beskydy, Vysočina, Moravské Budějovice, Česká Lípa, Bakov nad Jizerou, Pardubice, Kolín, Hradec Králové, Dobříš, Brno a jiný) i zahraniční (např́íklad Bratislava, Dunaj, Slovensko, Budapešt', Holandsko, Melbourne, Řím, Benátky, Houston, Videñ, Havana, New York, Berlin, Sumatra, Celebes, Arktida, Afrika, Aljaška, Sibiř atd.) určitě nemají dokumentární topografickou funkci, ale podle našeho soudu ani funkci konotační, nejspíš nesou, už svým množstvím, jen funkci deskriptivní.

Časovou dimenzi prríběhů z druhé poloviny dvacátého století pak vymezují připomínky reálných událostí (např́íklad oslavy Říjnové revoluce, výstava Země živitelka) a prostř̌edků (časopis „Mateřídouška“, noviny „Mladá fronta“, „Rudé právo“, „Lidová demokracie“, soudruh Mrkos, televizní soutěž Desetkrát odpověz, časopis „Večerní Praha“, fanfáry na trubku Vzhưru pionýř a Do nových dnü, holicí čepelka Vítěz, ČTK, TASS, Prensa Latina, agentura Reuter a podobně).

Mnoho chrématonym, skutečných vlastních jmen, která se v textu Hofmanových próz objevují, rovněž dokresluje nejen zájmy a vnitřní svět dětských hrdinů (např́ílad stolní hry Bylo - nebylo, Člověče, nezlob se a podobně), ale hlavně autorův subjektivní svět, jeho poznatky, vědomosti a zážitky. Jsou to mimo jiné i názvy písní (Rudý šátek pionýrů, Červený šátečku, kolem se toč, Bandera rossa, Hej, Slované, Ovčáci, čtveráci, Skákal pes, Ach, synku, synku), hudebních skladeb (Skočná - Smetanova polka ze symfonického cyklu Má vlast), árie (Směj se, paňáco, Barcarola, La Paloma, Vzpomínka na Milano), populárních současných i historických postav (Lindberg, Daidalos, Thor Heyerdal, Čestmír Böhm, Einstein, Gagarin, Raquel Welchová, plakát s Karlem Gottem), knih (O letadélku Káněti, Dvacet tisíc mil pod mořem, pohádka o Měsičníku, Vètrníku a Slunečníku, Osamělá vlčice), filmů (Frigo na mašině, Nerozlučni přátelé, Tři ořišky pro Popelku, Přestřelka na hranicich), novin, časopisů (Květy, Svět motorü, Pionýr, Svět v obrazech, Letem světem, Pestrý týden, Světozor), televizních pořadů (Desetkrát odpověz, Nad dopisy diváků, Vlaštovka), rovněž se v textech objevují i propriální připomínky filmových a literárních hrdinů (Chaplin, Frigo, Vinnetou, Robin Hood, kapitán Nemo, Odysseus, Pipi Punčochatá, Křemílek a Vochomůrka, Heidi, Ferda Mravenec, Jeníček a Mařenka, klaun Ferdinand, komisař Maigret, Fantomas, major Zeman, víla Amálka, delfín Filip, kačer Donald, pes Pluto), v té době populárních sportovců a sportovních oddílů (Golonka, Muhamad Ali, automobiloví závodníci Stirling Moss a Fangio, Inter Milán). 
Tato propria nemají však snad jinou funkci než funkci kolokační (k tomu blíže viz Pastyřík, 20004). O jejich dalších možných funkcích značně pochybujeme. Pro současného dětského čtenáře je ovšem celá Hofmanova bohatě dotovaná krajina jmen poměrně nepřehledná, protože jednak se už tak výrazně proměnila domácí společenská a politická situace, že situaci v druhé polovině minulého století popisované v Hofmanových prózách nemůže mladší a mladý čtenář porozumět, jednak odvádí svou kvantitou pozornost mladého čtenáře od vlastního prríběhu. Ř́ká-li například Carnegie Dale ${ }^{5}$, že dodáním proprií získá reprodukovaný př́íběh na věrohodnosti, zde jsme spíše svědky kontraproduktivního působení přemíry jmen.

Obracíme-li většinou ve stylistických a literárně onomastických studiích pozornost $\mathrm{k}$ vlastním jménům $\mathrm{v}$ literárních textech ${ }^{6}$, můžeme obvykle a nejčastěji postupovat dvěma směry. Za prvé si můžeme všímat proprií pouze $\mathrm{v}$ jednom díle, čímž většinou dospíváme $\mathrm{k}$ hlubší analýze konkrétního díla i autorových intencí, za druhé lze ovšem také obrátit pozornost k celému autorovu dílu, abychom totiž právě komplexnějším pohledem dospěli k hlubšímu a obecnějšímu poznání autorova jazyka a stylu vůbec. Je tedy na našem vlastním výběru, jakého cíle se snažíme dobrat, $\mathrm{k}$ jakému cíli směřujeme.

Existuje ovšem i další možná cesta, kterou jsme si zvolili tentokrát: cesta $\mathrm{k}$ lepšímu poznání funkcí vlastních jmen v literárním textu. Co z našeho materiálového šetření vyplývá?

Vlastním jménům osob (literárním antroponymům) Ota Hofman nevěnuje př́liš autorské pozornosti. $\mathrm{V}$ jeho knihách se sice vyskytují postavy pojmenované základními druhy antroponym, např́klad jen rodným jménem (Leoš, Ivan, Petr, Irena, Lucie, Saša, Richard, Rudla, Martin, Pavel, Jonáš, Jana, Marcela, Jitka, Milena), většinou se ale $\mathrm{v}$ těchto př́ípadech jedná pouze o výčet jmen postav z dětských kolektivů — spolužáci, kamarádi, děti ze školky a podobně — které jsou zmíněny jen jednou $\mathrm{v}$ jakémsi schematickém výčtu, aniž by s nimi autor dál pracoval. Jiná skupina postav je zase klasicky pojmenována neutrálním matrikovým spojením rodného jména s př́imením (Eva Samková, hlídač Jan Novák, Petr Stejskal, Irena Hladíková, Josef Zapadlo, řidič Josef Král a podobně), aniž by se tato propria objevila $\mathrm{v}$ textu více než jedenkrát. Proč? A autor maximálně využívá nominační funkci těchto proprií, která z užitých vlastních jmen vytváří pouze ilustrující kulisu.

I když se v Hofmanových knihách vyskytují postavy pojmenované pouze př́ijmením (např́íklad vrátný pan Tondl, doktorka Halásková, doktor Milota, Kleňhová, Besserová, Tưma, Andršt, děda Fialư, výhybkář Jouza, Hanousek, kluk Hamala, spolužáci Sommer, Slipejš, Jokl, Exner, soused Kraus, pan Miller,

\footnotetext{
${ }^{4}$ S. Pastyř́ík, Vlastní jména v literatuře a škola, Hradec Králové 2000.

${ }^{5}$ C. Dále, Jak mluvit a působit na druhé při obchodním jednání, Praha 1992.

${ }^{6} \mathrm{~K}$ tomu viz výbornou a ucelenou bibliografii české literární onomastiky od Ž. Dvořákové — eadem, Literární onomastika. Antroponyma, Praha 2017, s. 223-252.
} 
pan Tůma, Mach, Šiklová, Jarý, Mifková, Viehwegová, Teubner, Vodrážka, Šíp, Fiedler, Horáček, Komrs a jiný) a dětské postavy zmiňované pouze pod přezdívkami (Ruka, Rychlá noha, Mstitel, Bizon, Pind'a, Chemik), ani jejich množina není př́lišs bohatá či vynalézavá. Nestandardizovaných antroponym, která by prozrazovala např́íklad autorovy sympatie či citové zaměření, zde mnoho nenajdeme, a když, pak zase jen ve výčtech (Saša, Rudla, Andělka, Katka, Zuzanka, Kateřina, Michalka, Olina, Magda, Frantík, Pepík, Káta, Honza).

Funkce literárních antroponym, kterými se velmi často literárně onomastické studie právě zabývají, jsou v Hofmanových knihách kromě identifikační funkce maximálně potlačeny. Dokonce se domníváme, že převážná většina literárních antroponym má v Hofmanových př́bězích ojedinělou statickou quazivýčtovou, to je enumerickou funkci jako např́klad ve výčtu členů zmrzlinářovy rodiny Tino Marino, paní Marinová, děti: Tino, Angelo, Gina, Mína, Tina, Luigi, César. Chrématonyma pak mají v Hofmanových knihách svým dobovým zakotvením především funkci kolokační, eventuálně některá též ilustrační. Identifikační funkce je u nich většinou potlačena na úkor funkce ilustrační.

A toponyma, kterých je v Hofmanových knihách také hodně, mají rovněž ponejvíce jen funkci ilustrační.

Zoonyma se v Hofmanových prríbězích nevyskytují tak často, jak bychom v dětských knihách očekávali: kocour Odysseus je sice dokonce jedním z hrdinů knihy (jeho jméno se objevuje už i v názvu knihy Odysseus a hvězdy), ostatní zviŕata a jejich jména jsou ale $\mathrm{v}$ Hofmanových prózách především jen zmiňována — v Červené külně je to pes Rex a setr Ronny, v Klaunu Ferdinandovi papoušek Robert a orel Pepík, pes Punta se objevuje v Hodině modrých slonů, pes Džulbris v Útěku, medvěd Miša v Pohádce o staré tramvaji, psi Asta a Nero a žravá ryba Žižka v Lucii, postrachu ulice. Nejčastěji jsou použita zoonyma v knize Pan Tau a tisíc zázraků: např́klad pes Dorián, kočka Liza, papoušek Robert, boxer Alfred, pes Hanibal, pudl Cézar atd.

Méně obvyklým stylistickým prostředkem jsou v Hofmanových prózách propriální shluky ve formě výčtů, které právě svou enumeričností podtrhují hlavně kvantitativní údaje, dost možná ale sdělují i cosi o kvalitativním hodnocení takto pojmenovávané skutečnosti, např́íklad těsně za sebou uváděná propria Růžová ulice, Liliová ulice, Na Vršičku, Bezová, Šeřiková, Mátová, Okrajová (Klaun Ferdinand a raketa); spolužáci Sommer, Slipejš, Jokl, Exner, Wohlgenuth v próze Útěk; v Hodině modrých slonů autor jedním dechem pouze vypočítává děti ve školce: Ivan, Petr, Magda, Irena, v knize Lucie, postrach ulice se objevuje shluk pojmenování ryb, v Červené kůlně jsou zase objektem propriálního shluku chrématonyma vín (oinonyma), ba dokonce i nápisy na náhrobních kamenech na hřbitově apod.

A jak je to tedy s Hofmanovým „plastickým viděním situace“ $z$ hlediska literárně onomastických funkcí? 
Propria v Hofmanově repertoáru rozsáhlé krajiny jmen nesou hlavně funkci nominační, onomaziologickou, a funkci ilustrační. Chrématonyma pak na sebe nabírají kromě funkce ilustrační ještě také funkci kolokační, protože v prvé řadě pomáhají autorovi především výběrem blíže charakterizovat čas (druhou polovinu dvacátého století) a místa jednotlivých příběhů.

\section{Bibliografie}

Chaloupka O. a kol., Čeští spisovatelé literatury pro děti a mládež, Praha 1985.

Dále C., Jak mluvit a působit na druhé při obchodním jednání, Praha 1992.

Dvořáková Ž., Literárni onomastika, Praha 2017.

Majtánová M., Jména postav ve „, Slovenských pohádkách” Boženy Němcové, ZMK, 13, 1972, s. 391397.

Majtánová M., Vlastní jména osob v „Národnich báchorkách a pověstech” Boženy Němcové, ZMK, 12, 1971, s. 377-387.

Pastyřík S., Hypokoristika v povídkách Boženy Němcové. In: Prameny díla, dilo pramenem, ed.

J. Bartůňková, Hradec Králové 1995, s. 191-196.

Pastyř́k S., Vlastní jména v literatuře a škola, Hradec Králové 2000.

\section{The vast land of names in Ota Hofman's literary works}

\section{Summary}

The article is an analysis of proper names in the oeuvre of one of the best known Czech authors in the second half of the 20th century. The author discusses their various functions in literary texts, stressing at the same time the strong link between Hofman's works and the current social situation, which effectively prevents their publication in the new, changed times.

Keywords: Ota Hofman, literary text, proper names 